\title{
Conformationally Restricted Ratiometric Fluorescent Receptor for the Recognition of Adipate
}

\author{
Tae Young Joo, Narinder Singh, Hee Jung Jung, and Doo Ok Jang \\ Deparment of Chemistry, Yonsei Lniversity, Honju 220-710, Korea. E-mail dojangânonseiac.kr \\ Received December 7, 2007
}

Key Words : Ratiometrỵ, Diçarboxỵlate. Fluorescence. Adipate

Qualitative and quantitative detection of anions is an inspiring research area in chemical, biological. and environmental sciences. ${ }^{1}$ Among the anion sensing. dicarboxylate recognition is of interest because of the pronounced applications of dicarboxylates in industry and biological systems. ${ }^{-}$For the estimation of minute quantities of dicarboxylates. the fluorescence spectroscopy is ideally suited owing to its high sensitivity. Most of the reported chemosensors exhibit single-wavelength detection of fluorescence intensity. which is the simplest and most commonly used procedure $^{3}$ However. this procedure has suffered from various factors such as instrument effects (the brightness of the light source or the sensitivity of the detector), concentration of sensor molecules, and environmental effects. ${ }^{+}$The ratiometric fluorescence methods that are being used to tackle these problems operate by applying the intensity ratios of two different enission wavelengths. ${ }^{5}$

Developing a chemosensor for dicarboxylates having a long spacer is difficult because they exhibit a variety of structures and conformations. ${ }^{6}$ Thus, it is a challenging task to develop ratiometric fluorescence chemosensors which have the wavelength-dependent and substrate-dependent enission properties for a specific dicarboxylate. This target can be achieved by providing suitable binding sites in a rigid macrocycle or in a conformationally rigid linear receptor.

As part of our ongoing research, ${ }^{7}$ we have designed a benzimidazole-based conformationally rigid linear receptor. The benzinidazole moieties connected with a single bond may show a shift in fluorescence band owing to the restriction in the rotation of two benzinidazole groups upon complexation of dicarboxylates in 1:1 stoichiometry. This 1:1 stoichionetry will be responsible for recognizing dicarboxylates with a large spacer length.

The desired receptor was synthesized by adopting the literature procedure as shown in Scheme 1 . The spectroscopic data agree well with the formula of receptor 3 .
Receptor 3 upon excitation at $313 \mathrm{~lm}$ exhibits an emission at $450 \mathrm{~nm}$ in its fluorescence spectrum recorded with its 10 $\mu \mathrm{M}$ concentration in $\mathrm{CH}_{3} \mathrm{CN} / \mathrm{DMSO}(99: 1, v / v)$. The receptor can produce rationetric responses only with the dicarboxylate that can coordinate simultaneously with the binding sites of diatopic receptor 3 . In other words, receptor 3 is ideally suitable for dicarboxylates that can form a $1: 1$ hostguest complex. To decide the stoichiometry of complexes formed between receptor 3 and dicarboxylates, the continu-

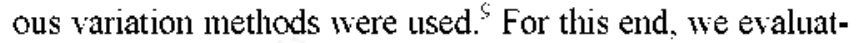
ed the influence of receptor $\mathbf{3}$ on dicarboxylates such as malonate. succinate, glutarate, adipate. pimelate and isophthalate in a $\mathrm{CH}_{3} \mathrm{CN} / \mathrm{DMSO}(99: 1, v / \mathrm{v})$ solvent system. The results are represented in Figure 1. This is the plot of fluorescence intensities of a series of solutions in which the molar fraction of the host $\{[\mathrm{H} \mid /([\mathrm{H}]+[\mathrm{G}])\}$ is changing although the total concentration of a host and a dicarboxylate guest remains constant. The results illustrate that the receptor-guest complex formed $1: 1$ stoichiometry only with adipate while all other surveyed dicarboxylates such as malonate, succinate. glutarate. pimelate and isophthalate

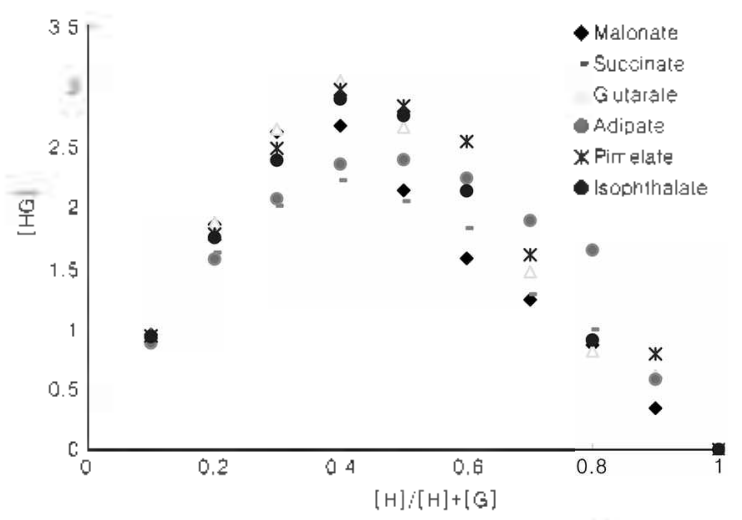

Figure 1. Job's plots showing the stoichiometries formed between receptor 3 and various dicarboxylates.

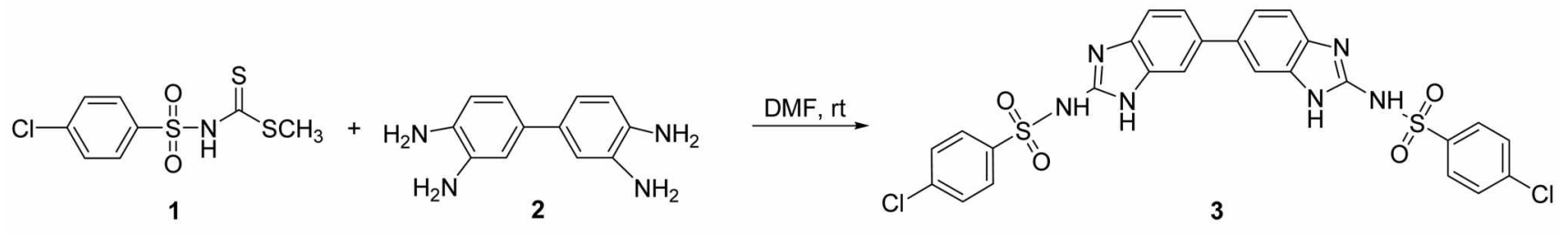

Scheme 1 


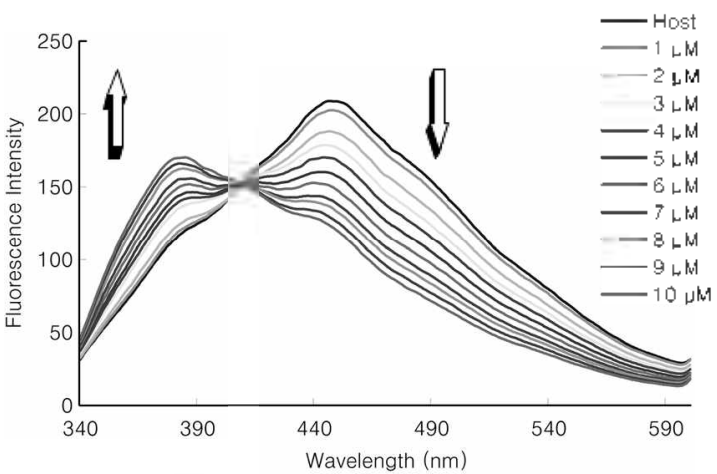

Figure 2. Changes in fluorescent spectrum of receptor $3(10, / \mathrm{M})$ upon addition of adipate $(0-10 / \mathrm{M})$ in $\mathrm{CH}_{3} \mathrm{CN} / \mathrm{DMSO}(99: 1$, w/v).

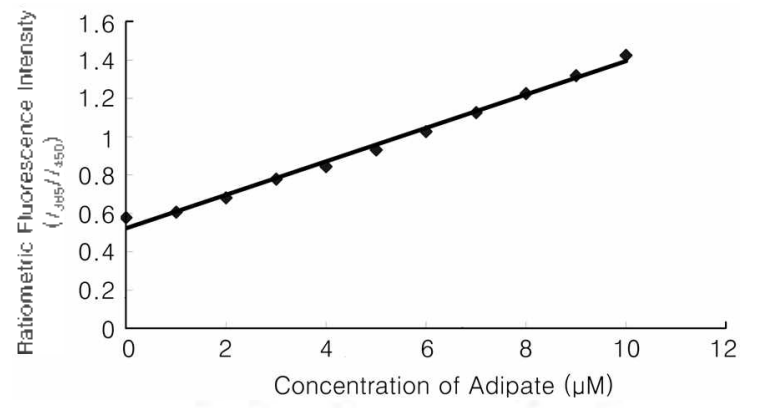

Figure 3. Changes un rationetric fluorescence intensity $\left(I_{33} / I_{450}\right)$ of receptor $3(10, / \mathrm{M})$ upon addition of adipate $(0-10 / \mathrm{M}) \mathrm{in} \mathrm{CH}_{3} \mathrm{CN} /$ DMSO $(99: 1, v / v)$.

showed the binding mode other than $1: 1$. This implies that these dicarboxy lates are either too short or too long to bridge the binding sites simultaneously.

To obtain quantitative information about the adipate binding affinity of receptor 3 . a titration was performed using the $10 \mu \mathrm{M}$ concentration of receptor $3 \mathrm{in} \mathrm{CH}_{3} \mathrm{CN} / \mathrm{DMSO}$ (99:1. $\checkmark / v)$ with continuous addition of tetrabutyl ammonium salt of adipate (Figure 2). With the successive addition of adipate the fluorescence intensity fell at $450 \mathrm{~nm}$. and a new band appeared at $385 \mathrm{~mm}$. No such significant fluorescence band shifts were observed with other dicarboxylates. The titration data were used to determine the binding constant of receptor 3 with adipate. On the basis of the BenesiHildebrand plot. ${ }^{l(1}$ the association constant $K_{\mathrm{a}}$ of receptor 3 for adipate was calculated to be $(2.4 \pm 0.2) \times 10^{-4} \mathrm{M}^{-1}$. The fluorescence ratiometric response of receptor 3 to adipate is displayed in Figure 3. The linear response of ratiometric fluorescence intensity to the increase of concentration of adipate clearly confirms that the receptor can be used for ratiometric estimation of adipate by using a calibration curve method. The receptor can detect a minimum of $1.0 \mu \mathrm{M}$ concentration of adipate. ${ }^{\text {l] }}$

It was assumed that the fluorescence band shift in the spectrum of receptor 3 upon binding with adipate is attributed to the molecular restriction in the rotation along the sungle bond between two benzumidazole moleties as shown in the binding mode $\mathbf{A}$, whereas the other dicarboxylates are binding through the mode $\mathbf{B}$ which has no restriction in the rotation along the single bond. ${ }^{12}$

In conclusion, we developed a linear benzimidazole-based fluorescent receptor capable of recognizing adipate. The receptor forms a $1: 1$ complex with adipate, restricting the rotation around the single bond between two benzimidazoles. This leads to the generation of two emitting states, offering the opportunity for rationetric recognition of adipate. The receptor can detect a minimum of $1.0 \mu \mathrm{M}$ concentration of adipate.

Acknowledgment. This work was supported by the Center for Bioactive Molecular Hỵbrids at Yonsei University.

\section{References}

1. (a) Gale. P. A. Acc. Chent Res. 2006. 39. 465. (b) Yoon. J.: Kim. S. K.: Singh. N. I.: Kim. K. S. Chem. Soc. Rev 2006. 35. 355. (c) Katayev. E. A.: Ustynyuk. Y. A.: Sessler. T. L. Coord. Chem. Rev: 2006. 250, 3004. (d) Davis, A. P. Coord Chem Rev 2006. 250. 2939. (e) Schmidtchen. F. P. Coord. Chem. Rav 2006, 250, 2918. (f) Bowman-James, K. Acc. Chem. Res. 2005, 38.671. (g) Gale, P. A. Coord Chent Rev 2003. 240. 167. (h1) Sessler. J. L.: Camiolo. S.: Gale. P. A. Coond Chent Rev 2003. 240. 17. (i) Suksai. C:: Tuntulani. T. Chem. Soc. Rev: 2003. 32.192 . (j) Gale. P. A. Coord. Chent. Rev: 2001. 213.79.

2. (a) Carvalho, S.; Delgado. R.: Fonseca, N.; Felix. V. New J. Chem. 2006. 30, 247. (b) Mao, H.; Rubakinin. S. S.; Sweedler, J. V. Anal. Chem 2005, 77, 7190. (c) Liu. S.-Y.; He, Y.-B; Wu, J.-L; Wei. L.-H.: Qin. H.-I.: Meng. L.-Z.: Hu. L. Org. Bionol. Chem. 2004. 2. 1582. (d) Nohta. H.: Sonoda. T.: Yoshida. H.: Sato $20 n o$. H.: Ishida. T.: Yamaguchi. M. J. Chomatogn . 2003.1010 .37 .

3. (a) Kim. H; Kang J. Bull. Koream Chem. Soc. 2007. 28,1531 . (b) In. S.: Kang, J. Bull. Korean Chem. Soc. 2005. 26. 1121 . (c) Martinez-Manez, R.: Sancenon, F. Chem. Rev 2003. 103, 4419.

4. Lakowicz. T. R. Topics in Fhorescence Spectroscopy: Plenum Press: New York. 1994

5. (a) Grynkiewicz. G.: Pcenie. M.: Tsien. R. Y. J. Biol. Chem. 1985. 260. 3410. (b) Banthia, S.: Samanta. A. J. Hhys. Chem. B 2006. 110,6437 .

6. (a) Massimo. B.; Marco, B.: Alberto, M.; Dario, P.: Angelo. T. New J. Chem. 2007. 31. 352 (b) Gomy. C.: Schmitzer. A. R. J. Org. Chent 2006. 71. 3121. (c) Yen. Y.-P.: Ho. K.-W. Tetrahedron Lett. 2006. 47. 7357. (d) Liu. S.-Y.: He. Y.-B.: Chant. W. H.: Lee. A. W. M. Tetrahedron $2006,62.11687$.

7. (a) Singh. N.: Jang. D. O. Org. Lett. 2007. 9, 1991. (b) Moon, K. S.; Singh, N.; Lee, G; Jang, D. O. Tetrahedron 2007. 63,9106. (c) Kiml. H. S.: Moon. K. S.: Jang. D. O. Sipromol Chem. 2006. 18. 97. (d) Kang. T.: Kiml. H. S.: Tang. D. O. Tetrahedron Lett. 2005. +6. 6079 .

8. Garin. J.: Melendez. E:; Merchan. F. L.; Merino. P.: Orduna, J:; Tejero, T. J. Heterocycl. Chem 1990, 27, 321.

9. Job. P. Am. Chim 1928.9.113.

10. Benesi. H.: Hildebrand. H. J. Am. Chent. Sox. 1949. 71. 2703.

11. Shortreed. M.: Kopelman1. R.: Kuhn. M.: Hoyland. B. Anal. Chen. 1996. 68. 1414.

12. (a) Kondo. S.-I; Sato, M. Tetrahedron 2006. 62. 4844 . (b) Kondo. S.-I; Kinjo. T.: Yano. Y. Tetrahedron Lett. 2005, t6. 3183. (c) MeFarland. S. A.; Finney. N. S. J. Am. Chem. Soc. 2002, 12t. 1178. 